\title{
Misinformation - Foreign Language Teaching Problems Resulting from the Perception of Reality and Communication Culture
}

\author{
Aleksandra Matulewska, Magdalena Wasielewska \\ Institute of Linguistics, Adam Mickiewicz University \\ ul. Międzychodzka 5, 60-371 Poznań \\ matulewski@poczta.onet.pl, m_wasielewska@o2.pl
}

\begin{abstract}
Abstact
This paper discusses the problems connected with mistranslation of idioms, emotionally marked expressions and false cognates. The purpose of the paper is to present the main foundations of misinformation and communication noise which result from the fact that foreign language learners are unaware of (i) the existence of false cognates, and (ii) the differences between the literal meaning and the implied one as far as emotionally marked expressions and idioms are concerned. It often causes communication breakdowns and equivalence deficiency in interlingual communication. The authors give examples of such idioms, emotionally marked expressions and false cognates and discuss the communicative aspects connected with such misinformation. Finally, the paper includes the suggestions of techniques which may be used by foreign language teachers in order to make the language learners aware of those problems. What follows at the end of the paper is a collection of four activities for English learners which are designed to teach them how to distinguish those problematic words and expressions and to make them understand the impact of communication noise on the messages produced by them.
\end{abstract}

What is the most difficult in every language is always that aspect which is different, specific within a given language reality, and not directly translatable into another language e.g. idioms and emotionally marked expressions. The methods of teaching idioms have varied so far. In secondary school teaching they appear as ephemerons - non-conventional foreign language teaching methods - which to some extent facilitate the process of idiom teaching, on the one hand, and idiom learning, on the other hand. Traditional teaching methods, which has been used so far, usually restrict themselves to dictating an idiom in a foreign language with its equivalent in the Polish language without sufficient cultural or context background. Although students and pupils know a certain number of such idioms, that lack of context makes them use such collocations incorrectly by inserting idioms in e.g. English texts in which they would not be used due to cultural reasons, while at the same time they would be justified in a similar text in the Polish language. 
One of the non-conventional foreign language teaching methods is the Total Physical Response $^{1}$ (TPR) - students or pupils are required to silently perform orders that is: listening and moving in the way strictly connected with order performance. As far as the idiomatic expressions are concerned this method may be applied only in the case of such expressions which to some extent may be presented in a graphic form of presentation. Memorizing takes place when the text heard is associated with its visualization.

The Counselling Language Learning (CLL) also known as the Community Language Learning is a method used less frequently in Poland but it should be stressed here that it brings better results in foreign language teaching. According to this method, the process of communication including foreign language communication takes place in a group of people. It is connected in an inseparable way with an interaction and communication between particular members of a group and therefore it is not a phenomenon which may apply to an isolated individual human being. What is more, there is one more assumption concerning this method that is: people who communicate like doing it only as far as the topic mentioned is interesting for them. It is one of the reasons why it is so difficult to put this method into practice in Polish schools which are limited by strict curricula. Therefore it is hard to have a wolf full and wether whole. Nevertheless if we decide to implement some modifications (which take into consideration the topics included in the curriculum and at the same time are interesting for pupils and students) we will be able to prepare such lessons or lectures that make everyone happy. Among the topics worth recommending here there are love, movies and music.

What seems to be a perfect supplement is an introduction of a natural method ${ }^{2}$ which assumes the dominant role of a recipient - that is listening to foreign language utterances. This natural way of foreign language acquisition (similar to the way in which children learn their native language) if connected with a discussion on an interesting topic results in a significant increase in activity among pupils and students during their lessons. By eliminating stress, the feeling of being ashamed due to making mistakes and all negative emotions connected with them, we can launch a natural effective process of foreign language acquisition including communicative knowledge acquisition. Pupils and students in a natural way acquire communicative skills and use suitable idioms and expressions in correct communicative situations. The exchange of opinions among students and pupils in which the teacher plays a supportive role only (being a coordinator, moderator and if need be a translator or interpreter who monitors the process standing aside) ensures teaching and learning a natural colloquial language including idioms, slang and fixed syntagmas.

When choosing a method or rather when creating a new one adjusted to the needs of a specific language course and its curriculum, first of all, we shall take into consideration the communicative aspect. The main stress should be placed upon the communicative skills - the ability to communicate successfully in a given foreign language. We may achieve it to a large extent by stressing the differences in mentality and the impact of such differences on the communication and interpretation of utterances. The literal meaning of an utterance may differ significantly and it is a rule that especially inexperienced foreign language learners misinterpret unknown texts by translating them word-for-word what of course in the case of idioms may result in absurd linguistic structures. Apart from the difficulties connected with recognizing and translating idiomatic expressions as an indivisible unit instead of word-for-word misinterpretation, there is also a problem of cultural discrepancies which may describe such elements of the source-language culture and source-language reality which have no equivalent in a target language due to the lack of such designates in the latter. Being unconscious of such discrepancies and deficiencies makes foreign language learners prone to misinterpretation. When they realize that they are unable to code and decode messages in a foreign language their willingness to use the non-native language decreases. Instead of improving their language skills they become frustrated and depressed and as a result the

\footnotetext{
${ }^{1}$ The method introduced by James Asher in the 70s in the USA.

${ }^{2}$ The method introduced by Tracy Terrella and Steven Krashen in the 70s in the USA.
} 
communication barriers are created and enhanced. Therefore, the teaching results decrease as well. A similar problem is connected with not paying attention to grammatical form and its impact on the meaning or not stressing phonetic differences between the source and target languages and the difference in meaning which is a direct result of the major pronunciation mistakes made because of assimilating and identifying foreign-language sounds with the native language ones.

The method of a foreign language teaching which has recently been widely promoted ${ }^{3}$ is a play. Using various plays is the best way to show cultural differences and communication difficulties connected with them. Teaching idioms we cannot limit ourselves just to giving students Polish equivalents. It is also necessary to indicate situations in which we can use such expressions, in which we can verbalize them. Thus, we must give not only the English usage but also Polish one as they do not necessarily overlap in all contexts.

What follows below is a sample of plays for English learners. They have been prepared in response to the demand for more ideas to develop communication skills in the classroom. Their aim is to give foreign language students of English specific practice in the communication skills as far as the idioms and other types of fixed expressions are concerned in order to develop their fluency and communication effectiveness. The material used addresses a range of secondary school and university student themes which do not require specialist knowledge. However, they may require from the teacher the introduction of some thematic vocabulary which will enable and facilitate taking part in the plays. The material is completely independent of any course book and can, therefore, be used on any English course. The activities are aimed at learners of English at an intermediate level or above. All of the activities are intended for groups of at least two people. In the cases where the number of participants has been specified by the roles allocated the teacher can add or reduce the number by making small changes to the agenda. The aim of the activities is to make every single member of the group speak.

\section{ACTIVITY 1}

\section{Long and Short Vowel Sounds /i:/ and /i/}

This activity deals with the differences between the quality of vowels in English and Polish. The difference between the vowels /i:/ and /i/ should be pointed out to students as this can be a very sensitive issue. The differences between the intended messages and the produced utterances should be stressed by the teacher before the activity starts.

A teacher should warm up the group by presenting pairs of words having those two vowel sounds and practicing pronouncing them. It is necessary to make them sensitive to the differences in meaning in such pairs where the change of the quality of the vowel changes the meaning (e.g. bitch versus beach; hill versus heel; etc.). Inform them that in order to produce /i:/ they should keep pushing the body of the tongue forward and spread the lips; while in order to produce $/ \mathrm{i} /$ they should pull the tongue back and down toward /ə/, and make sure the lips are neutral. Let them practice producing those two sounds until they feel the difference.

Assign the roles and allow them to read through the vocabulary given on the pieces of paper. Ask the students to tell each other about their imaginary holidays using the vocabulary. Assign one secretary to each group who is going to make notes and check which words with those two vowel sound were used by the speakers. Let the secretary comment on the notes and check whether they interpreted the messages correctly by producing intended sounds. Give the students language and communication feedback informing them about the possible communicative problems which may result from mispronouncing those two sounds.

\footnotetext{
${ }^{3}$ H. Komorowska (1988, 2001), T. Siek-Piskozub (1994, 2001)
} 


\begin{tabular}{|l|l|}
\hline Student 1A & Student 1B \\
Bitch & Beach \\
Heat & Heat \\
Rich & Rich \\
Sheep & Ship \\
\hline Student 2A & Student 2B \\
Sheep & Ship \\
Beach & Beach \\
Hit & Heat \\
Rich & Rich \\
& \\
\hline Student 3A & Student 3B \\
Hit & Hit \\
Sheep & Sheep \\
Beach & Bitch \\
Shit & Reach \\
\hline Student 4A & Student 4B \\
Ship & Ship \\
Shit & Sheet \\
Reach & Heat \\
Beach & Bitch \\
\hline
\end{tabular}

\section{ACTIVITY 2}

\section{False Friends}

This activity deals with English and Polish false friends. The apparent similarities between the words which sound similar should be pointed out to students as this can be a very sensitive issue. The meaning of the intended message and the produced utterance should be stressed by the teacher before the activity starts.

A teacher should warm up the group by presenting English false friends and ask them to guess their meaning.

Ask them to use dictionaries in order to find their meaning. Then give the English equivalents for Polish words which may be incorrectly associated with those false friends. Make them sensitive to the importance of memorizing such words and checking in a dictionary the meaning of apparently known words.

At the end of the activity check the results and correct any mistakes.

\begin{tabular}{|l|l|}
\hline sympathy & współczucie \\
\hline sympathetic & współczujący \\
\hline pathetic & żałosny \\
\hline pathos & żałość \\
\hline actual & właściwy \\
\hline actually & właściwie \\
\hline eventual & ostateczny \\
\hline eventually & ostatecznie, koniec końców \\
\hline preservatives & konserwanty \\
\hline public house & pub \\
\hline conception & poczęcie \\
\hline carnation & goździk \\
\hline fabric & materiał, tkanina \\
\hline
\end{tabular}




\begin{tabular}{|l|l|}
\hline sympatia & liking \\
\hline sympatyczny & nice \\
\hline patetyczny & pompous \\
\hline aktualny & up-to-date, current \\
\hline aktualnie & at present \\
\hline ewentualny & possible, probably \\
\hline ewentualnie & if need be \\
\hline prezerwatywy & condoms \\
\hline dom publiczny & brothel \\
\hline koncepcja & ideal, concept \\
\hline karnacja & complexion \\
\hline fabryka & factory, plant \\
\hline
\end{tabular}

\title{
ACTIVITY 3
}

\section{Panel Discussion}

This activity deals with the culture of taking part in a discussion and understanding mentality. The activity is designed rather for a bigger group (up to 18 participants). The aim of this activity is to use certain utterances expressing the attitude toward the opinion heard and giving opinions.

Explain students the differences between the Polish and English ways of having a discussion. Point out the differences in mentality and polite ways of agreeing and disagreeing.

Ask the students about their opinion on abortion and divide them into two groups one for and the other one against abortion.

Give the students their role-cards, and ask them to use the expressions given at least once and to present their argument.

It is possible to introduce one more participant - a chairperson - who is going to open the meeting, welcome and introduce the participants and state the aim of the meeting. Finally, the chairperson should give floor to the participants.

\author{
Student 1 FOR \\ I think you are wrong. It's not ... \\ I feel you are right ... \\ Every woman has a right to decide whether she wants to give birth to a baby or not.
}
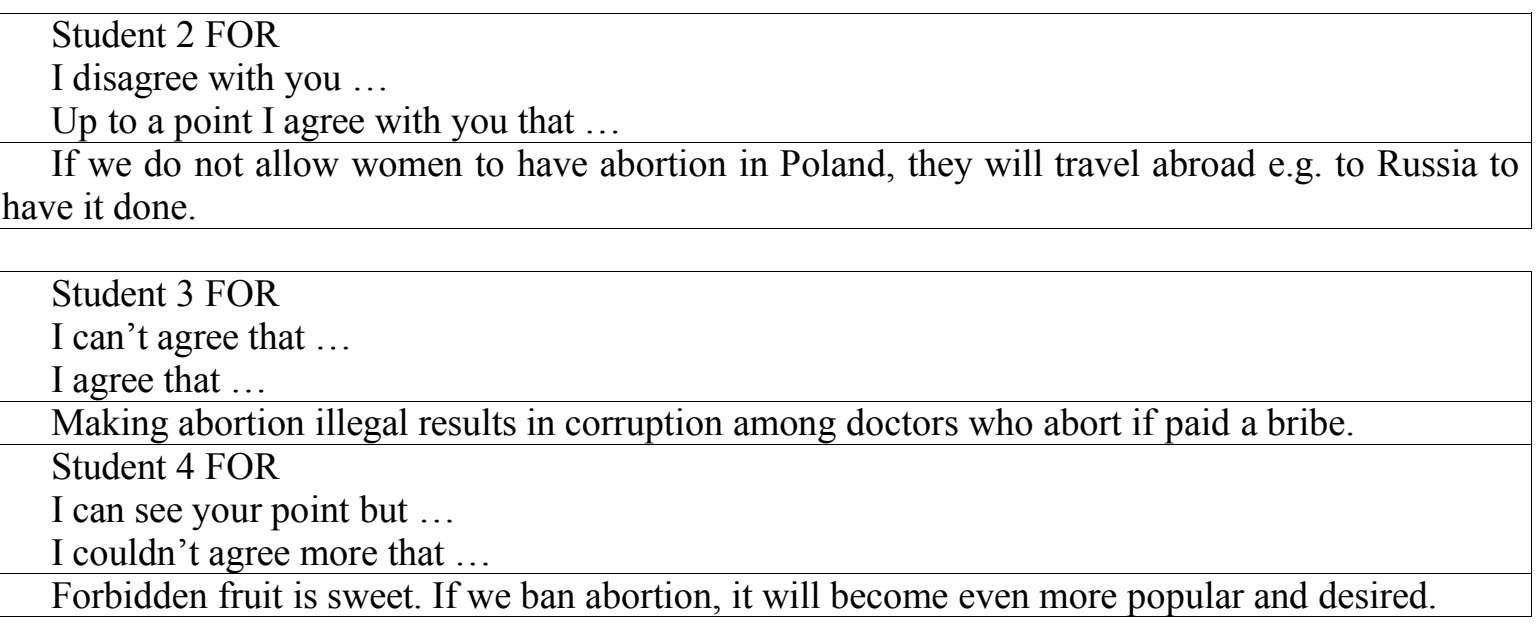


\title{
Student 5 AGAINST
}

I think you are wrong. It's not ...

I feel you are right ...

If something is illegal then there is social pressure to obey the law so in consequence less women decide to abort their child.

\author{
Student 6 AGAINST \\ I don't think you are right ... \\ I totally agree with you... \\ A fetus from the moment of conception is a human being so aborting it is an act of killing.
}

\author{
Student 7 AGAINST \\ I think you are wrong. It's not ... \\ I feel you are right ... \\ If you do not want a child, you can use birth-control methods or refrain from having sex.
}

\author{
Student 8 AGAINST \\ I think you are right ... \\ I'm afraid I disagree with you \\ If someone is old enough to have sex, they should also be responsible for the consequences of \\ their behavior and therefore abortion should be illegal.
}

\author{
Student 9 AGAINST \\ I couldn't agree more ... \\ I totally disagree with you ... \\ No one has right to kill and abortion is an act of killing an unborn child.
}

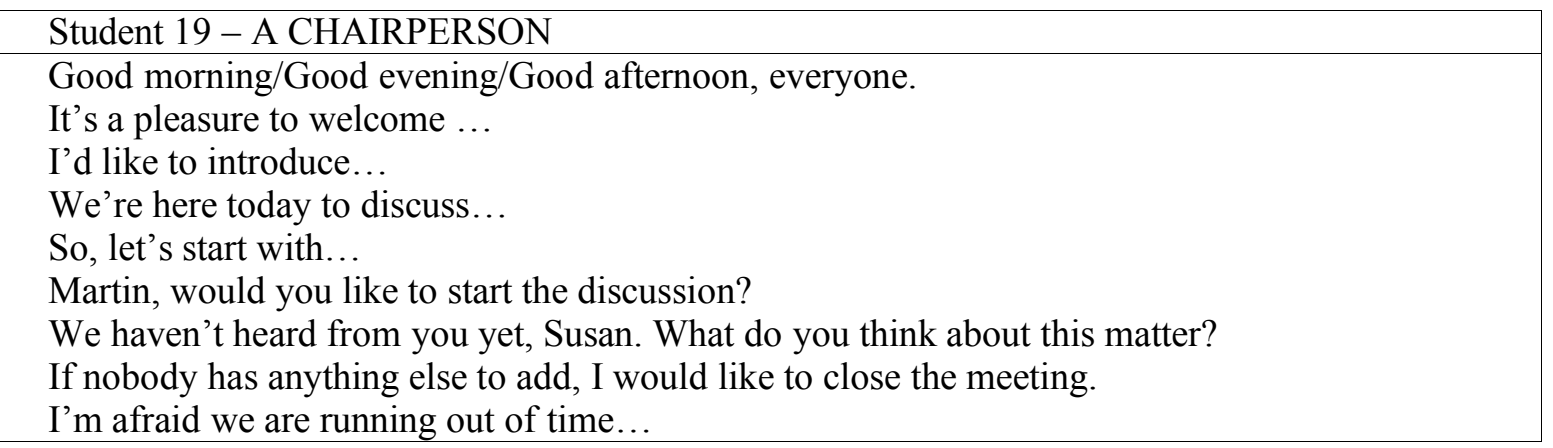

\section{ACTIVITY 4}

\section{Matching 1.}

a/ Students are divided into five or six groups. Each group receives the set of five pictures presenting five English idioms and five pictures of presenting corresponding Polish idioms. Students are to join the pictures into English-Polish pairs. Examples: ${ }^{4}$

\footnotetext{
${ }^{4}$ Pictures and idioms taken from М. Дубровин (1997), Иллюстрированный сборник идиом на пяти языках, Москва
} 
Group 1.
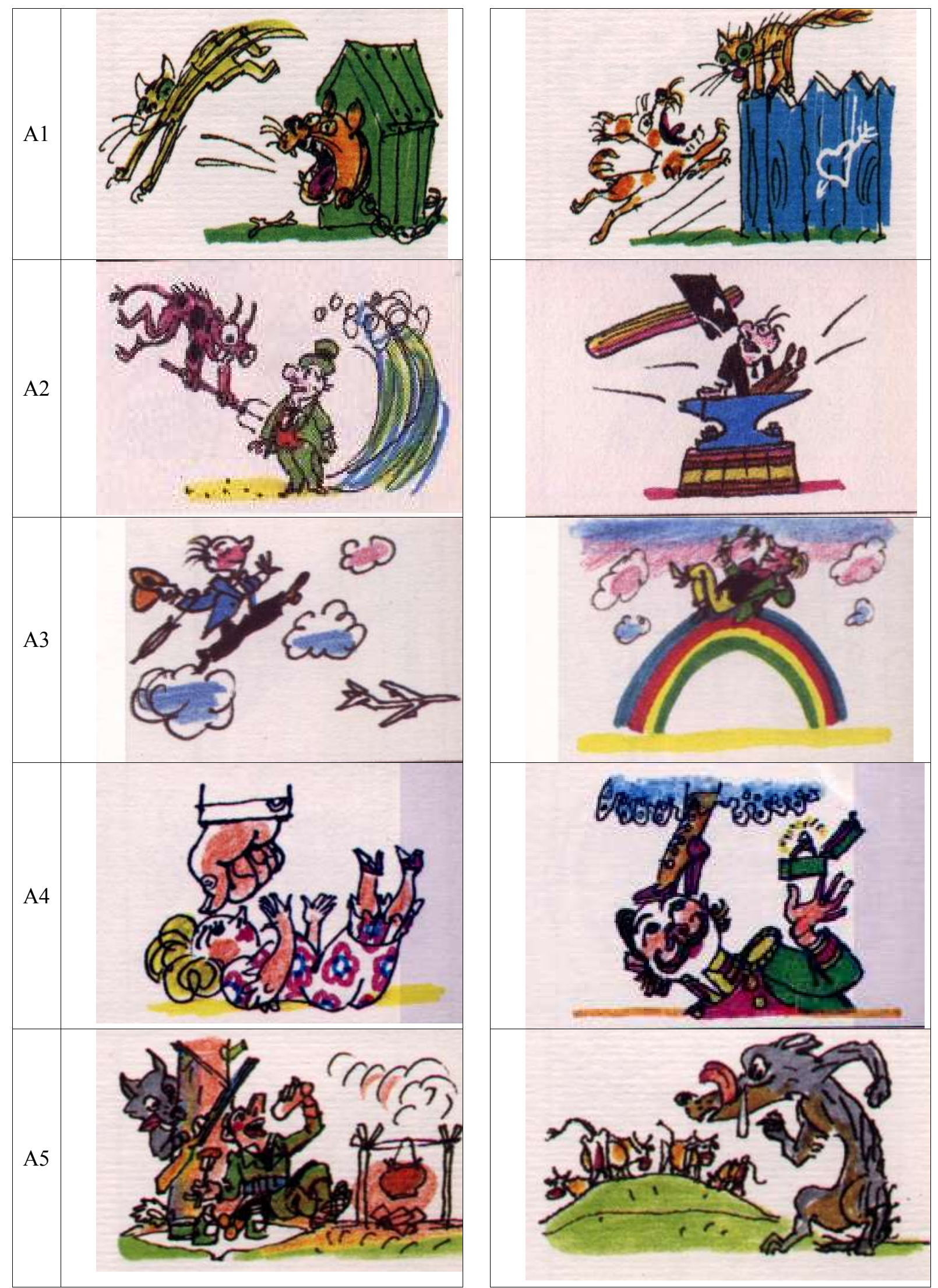
Group 2.
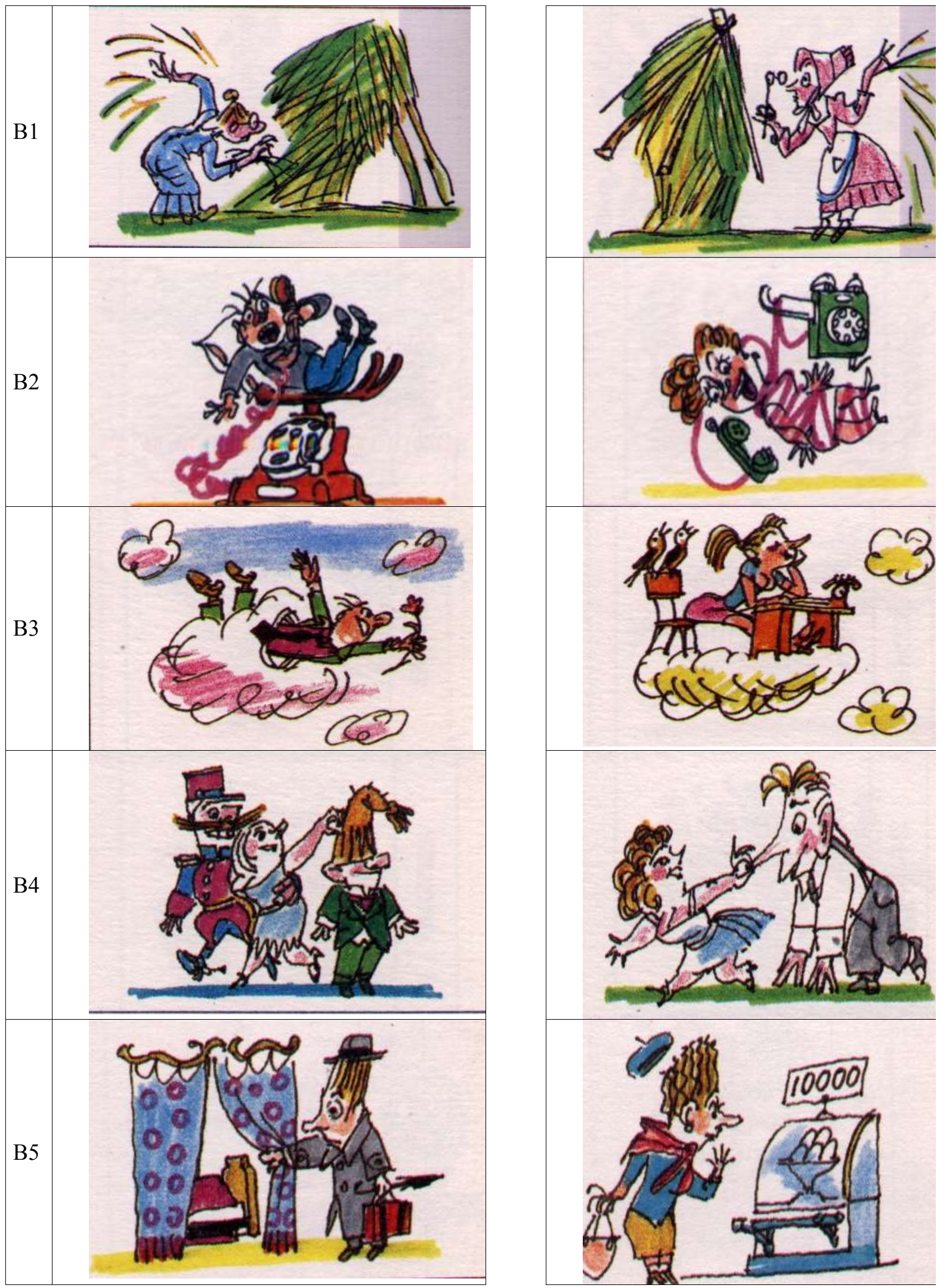
Group 3.
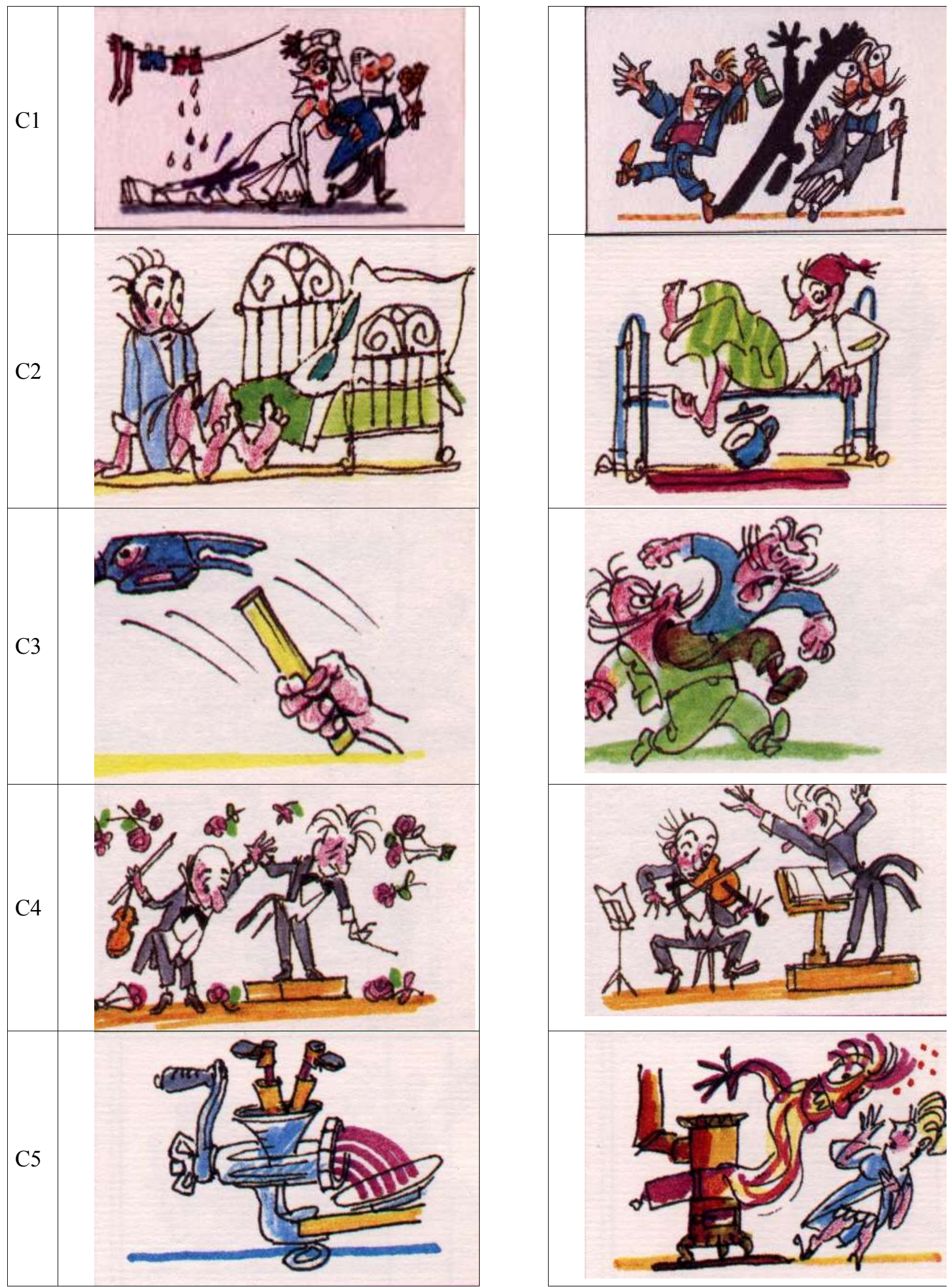
Group 4.
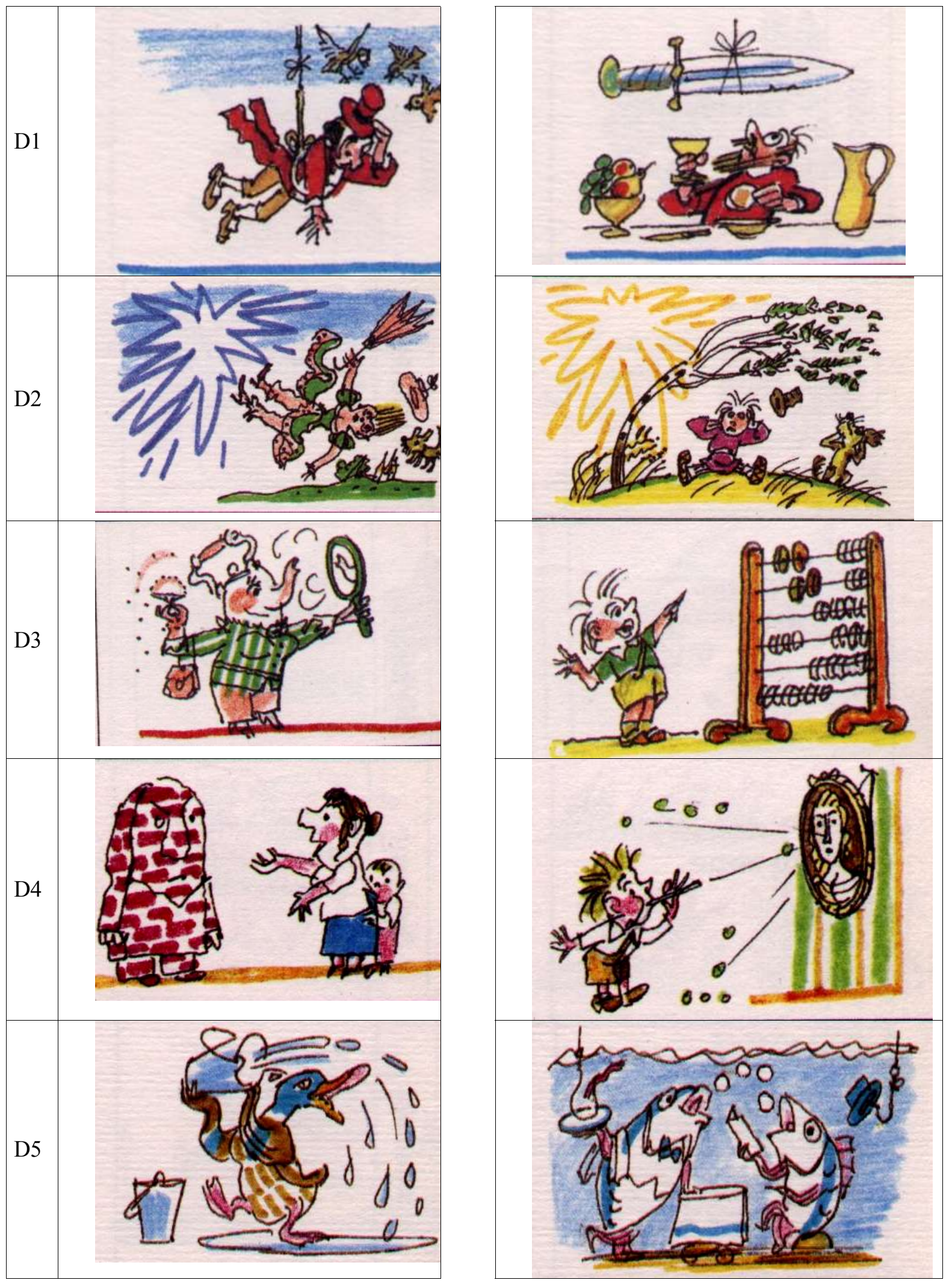
Group 5.
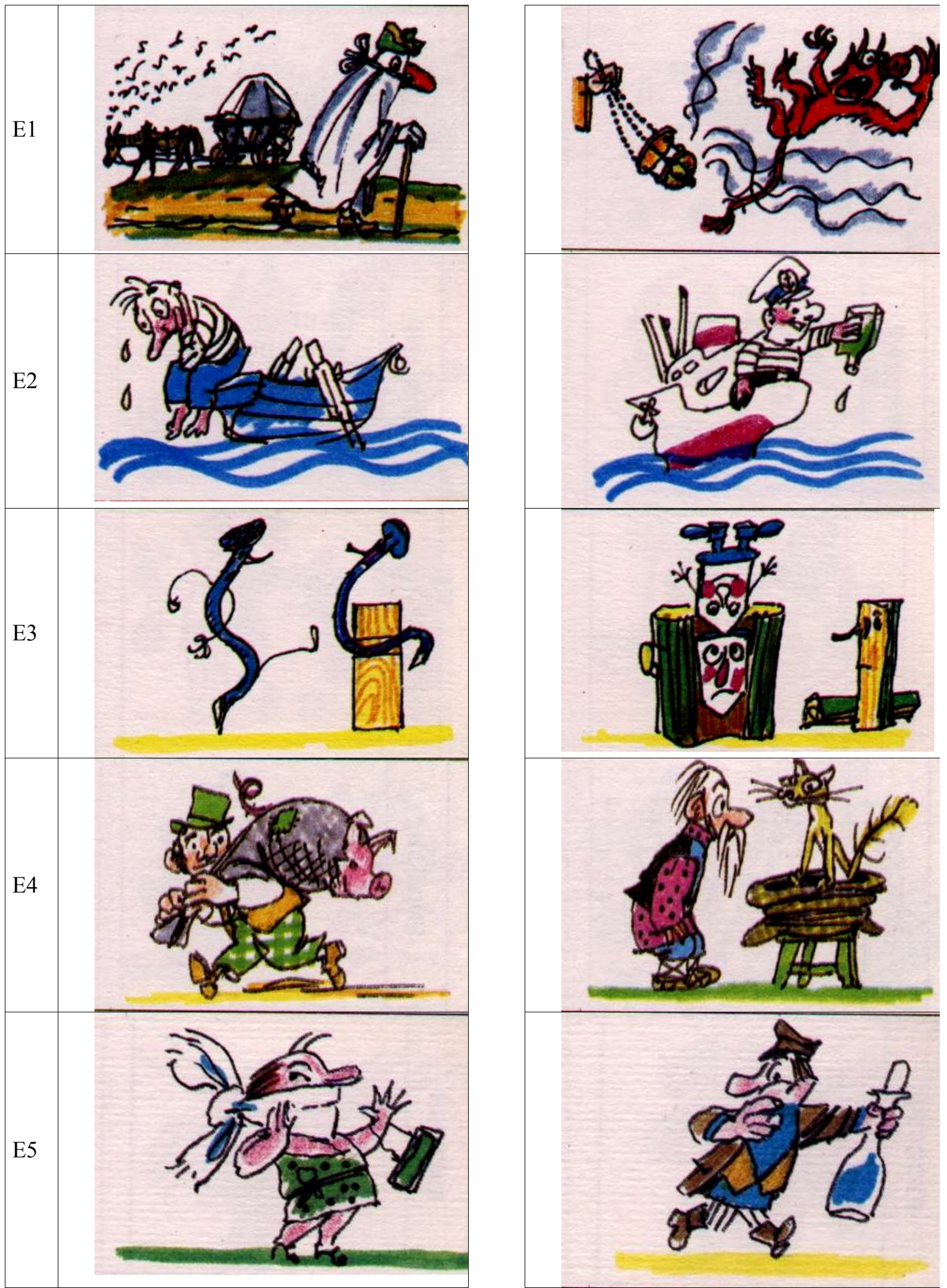
Group 6.
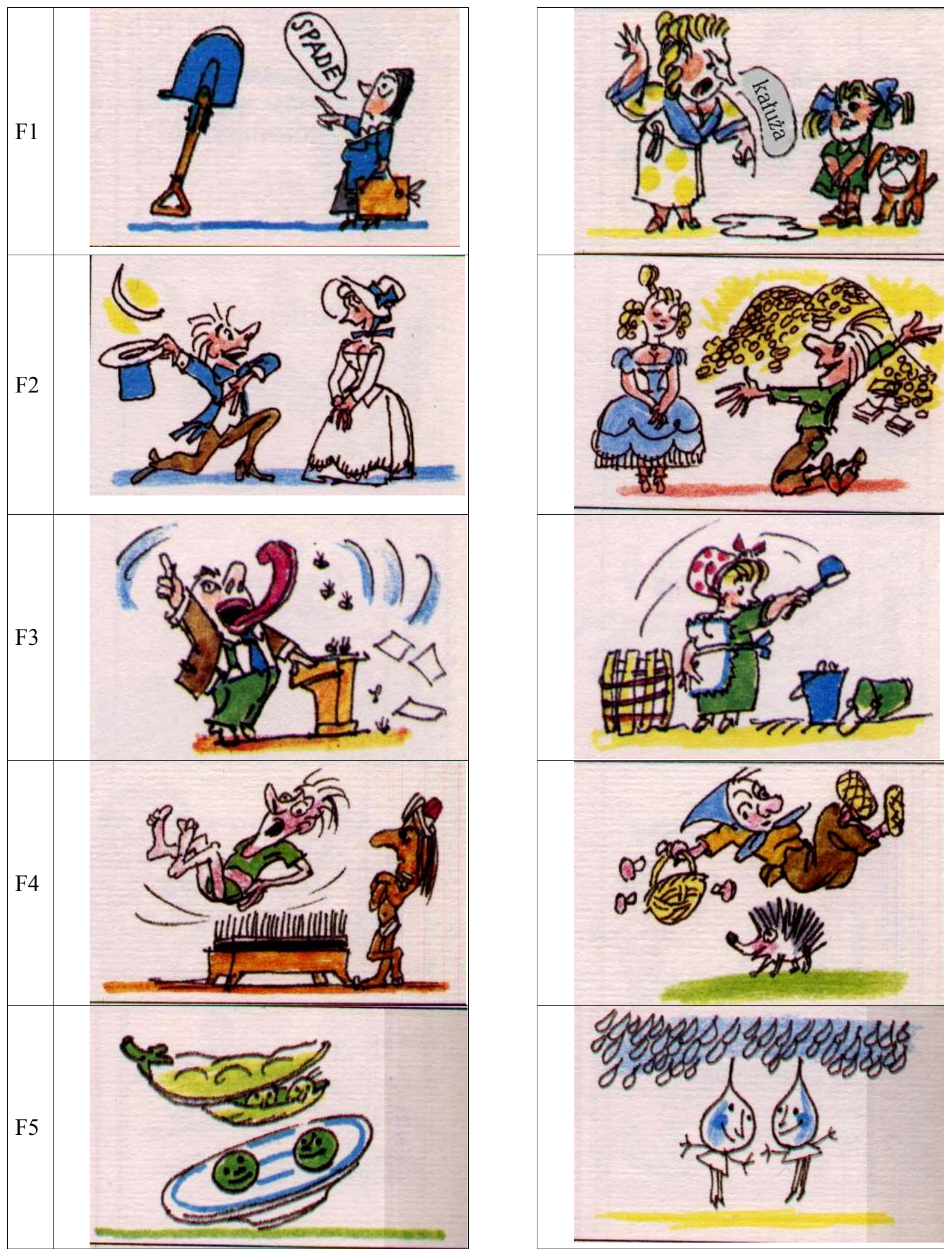
$\mathrm{b} /$ When the students match pictures, the teacher gives them pieces of paper with idioms written om them. Once the students match idioms to pictures the teacher checks their work and corrects any mistakes. Later the students are asked to use dictionaries and transalte those idioms literally in order to show them the nonsense of such transaltion products and the necessity to learn idioms by heart.

\section{Group 1.}

\begin{tabular}{|l|l|l|}
\hline A1 & To live a cat and dog life. & Żyć jak pies z kotem. \\
\hline A2 & $\begin{array}{l}\text { To be between the devil and the deep } \\
\text { blue sea. }\end{array}$ & Być między młotem a kowadłem \\
\hline A3 & To tread on air. & Być w siódmym niebie. \\
\hline A4 & To be under someone's thumb. & Być pod pantoflem. \\
\hline A5 & Hungry as a hunter. & Głodny jak wilk. \\
\hline
\end{tabular}

\section{Group 2.}

\begin{tabular}{|l|l|l|}
\hline B1 & To look for a needle in a haystack. & Szukać igły w stogu siana. \\
\hline B2 & To sit on the phone. & Wisieć na telefonie. \\
\hline B3 & To be up in the clouds. & Bujać w obłokach. \\
\hline B4 & To draw the wool over someone's eyes. & Wodzić kogo za nos. \\
\hline B5 & One's hair stands on end. & Włosy stają komu dęba. \\
\hline
\end{tabular}

\section{Group 3.}

\begin{tabular}{|l|l|l|}
\hline C1 & To cast a slur on someone's reputation. & Rzucać cień na kogoś. \\
\hline C2 & To get out of bed on the wrong side. & Wstać lewą nogą. \\
\hline C3 & To flay off the handle. & Wyjść z siebie. \\
\hline C4 & To play first fiddle. & Grać pierwsze skrzypce. \\
\hline C5 & To play with edge-tools. & Igrać z ogniem. \\
\hline
\end{tabular}


Group 4.

\begin{tabular}{|l|l|l|}
\hline D1 & To hang by a thread. & Wisieć na włosku. \\
\hline D2 & Like a bolt from the blue. & Jak grom z jasnego nieba. \\
\hline D3 & As plain as the nose on your face. & Jak dwa i dwa to cztery. \\
\hline D4 & You might as well talk to a brick wall. & Jak grochem o ścianę. \\
\hline D5 & To take something like a duck to water. & Czuć się jak ryba w wodzie. \\
\hline
\end{tabular}

\section{Group 5.}

\begin{tabular}{|l|l|l|}
\hline E1 & $\begin{array}{l}\text { To avoid someone or something like the } \\
\text { plague. }\end{array}$ & Bać się jak diabeł święconej wody. \\
\hline E2 & A drop in the ocean. & Kropla w morzu. \\
\hline E3 & Nail drives out nail. & Klin klinem. \\
\hline E4 & To buy a pig in poke. & Kupować kota w worku. \\
\hline E5 & To keep mum. & Nabrać wody w usta. \\
\hline
\end{tabular}

\section{Group 6.}

\begin{tabular}{|l|l|l|}
\hline F1 & To call a spade a spade. & Nazywać rzeczy po imieniu. \\
\hline F2 & To promise the moon. & Obiecywać złote góry. \\
\hline F3 & To beat the air. & Przelewać z pustego w próżne. \\
\hline F4 & To be on pins and needles. & Siedzieć jak na szpilkach. \\
\hline F5 & As like as two peas in a pod. & Podobni jak dwie krople wody. \\
\hline
\end{tabular}

\section{Matching 2}

Students are divided into the groups of four or five people. Each group receives a set of five idioms used in sentences with their definitions on separate pieces of paper. Their task is to join the idioms with corresponding definitions. 


\section{Sentences. Pair-work.}

Students receive two idioms and try to make sentences with them. Then they read out their sentences aloud, all the students take part in listening to the exemplary sentences and if need be the teacher supervises correcting any mistakes.

\section{Literature}

Cross, D. 1992. A Practical Handbook of Language Teaching, Prentice Hall International (UK) Limited.

Дубровин, М. 1997. Иллюстрированный сборник идиом на пяти языках, Москва.

Harmer, J. 1991. A Practice of English Language Teaching, Longman Group UK Limited.

Hirsch, E. D., Jr., Kett, J. F., Trefil J. 1988. The Dictionary of Cultural Literacy. What Every American Needs to Know, Houghton Mifflin Company.

Holden, S. 1981. Drama in Language Teaching, London: Longman.

Komorowska, H., red. 1988. Ćwiczenia komunikacyjne w nauce języka obcego.

Komorowska, H. 2001. Metodyka nauczania języków obcych, Warszawa: Fraszka Edukacyjna.

Seidl, J., McMordie, W. 1988. Fifth edition English Idioms, Oxford University Press.

Siek-Piskozub, T. 1994. Gry i zabawy w nauczaniu języków obcych, Warszawa: WSiP.

Siek-Piskozub, T. 2001. Uczyć się bawiqc: strategia ludyczna na lekcji języka obcego, Warszawa: PWN.

Stawna, M. 1991. Podejście komunikacyjne do nauczania języków obcych, Warszawa: WSiP.

Wessels, Ch. 1987. Drama, Oxford: OUP.

Woodward, T. 1991. Models and Methapors in Language Teacher Training, Cambridge: CUP. 